This is an electronic reprint of the original article. This reprint may differ from the original in pagination and typographic detail.

Author(s): Heikkinen, Suvi; Lämsä, Anna-Maija; Hiillos, Minna

Title: $\quad$ Narratives by women managers about spousal support for their careers

Year: $\quad 2014$

Version:

Please cite the original version:

Heikkinen, S., Lämsä, A-M. \& Hiillos, M. (2014). Narratives by women managers about spousal support for their careers, Scandinavian Journal of Management, 30 (1), 27-39. doi:10.1016/j.scaman.2013.04.004

All material supplied via JYX is protected by copyright and other intellectual property rights, and duplication or sale of all or part of any of the repository collections is not permitted, except that material may be duplicated by you for your research use or educational purposes in electronic or print form. You must obtain permission for any other use. Electronic or print copies may not be offered, whether for sale or otherwise to anyone who is not an authorised user. 


\title{
Narratives by women managers about spousal support for their careers
}

\begin{abstract}
A bstract
In this article we present a qualitative study of spousal support for the careers of women managers. The research material consists of the narratives of 25 women managers in Finland. The study has two main implications. Firstly, unlike previous studies, we use a narrative approach to demonstrate that a woman manager's career and spousal support are experienced as ambiguous and evolving over the career. The support was constructed by the women managers as flourishing, irrelevant, deficient or inconsistent. Secondly, to increase our knowledge about gender relations, we combine discussion of the topic with gender order analysis and suggest that gender order is critical for an understanding of the nature of spousal support. We conclude that a male spouse who is willing to break the traditional gender order and provide his wife with various forms of support is often constructed as having a positive influence on the career of his woman manager wife. The study calls attention to families as sites of doing gender.
\end{abstract}

K ey words: woman manager, career, doing gender, gender relation, gender order, family, spousal support, narrative, Finland

\section{Introduction}

A substantial body of research in the field of careers and management has drawn attention to the intersection of career and family for women managers (e.g. Powell \& M ainiero, 1992; White, 1995; Simpson, 1998; Blair-Loy, 2003; O' Neil \& Bilimoria, 2005; Duxbury \& Higgins, 2005; Ezzedeen \& Ritchey, 2008; Guillaume \& Pochic, 2009; Lämsä \& Hiillos, 2008). Recent research findings suggest that career and family are not separated, and that the relationship between them is multidimensional: not only do women's career experiences and outcomes affect their experience of family life, but also vice versa (Ruderman et al., 2002; Greenhaus \& Singh, 2004; Rothbard et al., 2005; Greenhaus \& Powell, 2006; Greenhaus \& Foley, 2007). Despite this growing interest in the effect which the family has on a woman's career (Powell \& M ainiero, 1992; Blair-Loy, 2003; Guillaume \& Pochic, 2009; M äkelä et al., 2011), previous research has paid little attention to what is meant by family, and has assumed a simple and unambiguous understanding of the term. With some few exceptions (e.g. Ezzedeen \& Ritchey, 2009; Gordon \& W helan-B erry, 2004), studies often ignore the fact that 
women managers' families consist of different members who may have different roles at different times during these women's career paths.

This study aims to fill that gap in research by studying empirically how women managers experience the support given them by their male partners from the perspective of their career. Spousal support has been researched to some extent for working women in general (Rosenbaum \& Cohen, 1999; Friedman \& Greenhaus, 2000; Gordon \& Whelan-B erry, 2004) and for women in executive positions (Ezzedeen \& Ritchey, 2008). However, these studies have not problematized support for a woman manager from her male spouse, and they have ignored the fact that such support is neither automatic nor unproblematic in the different twists and turns of a woman's career path (Ezzedeen \& Ritchey, 2008). Nor have these studies considered the argument that support is interconnected with power relations between spouses; power relations affect both the woman's career and the family context (Connell, 1987). Indeed, gender relations in the family can act as a key organizing factor, providing resources or imposing limitations on a woman manager's career (Gherardi, 1995; Kimmell, 2000). Thus, we are interested in what kind of gender relations women managers construct when discussing their experiences of spousal support for their career. In this study we use the concept of gender order to analyse the informal social arrangements that define the complex and changing patterns of gender relations (Connell, 1987), particularly between the woman manager and her spouse. Gender order not only describes the values, expectations and norms of what is appropriate for women and men, but also tends to create subordination, female and male domains, and segregation in status and occupations, power and knowledge.

Following recent methodological approaches in the field of career research (e.g. Cohen et al., 2004; Bujold, 2004; Y oung \& Collin, 2004; Cohen, 2006; Savickas et al., 2009), we use narrative methodology and in particular, life-course re-framing (Moen \& Sweet, 2004; Savickas et al., 2009), to explore how these women managers make sense of their spousal support for their career. The ontological and epistemological assumptions we have adopted here draw on social constructionism (Berger \& Luckmann, 1966) in its moderate form, which emphasises the socially and culturally embedded nature of meanings and knowledge, which are seen as created through language use and communication (West \& Fenstermaker, 1995; K atila \& M eriläinen, 1999; Lämsä \& Sintonen, 2001). Thus the woman manager is enabled to construct her career herself, using social and cultural conventions while linking disparate 
elements of her career together and connecting them to broader aspects of her life (B runer, 2004; Bujold, 2004; Chase, 2005).

The present study makes two key contributions to research in this field. First, we contribute to earlier research on women managers' careers and families by investigating the evolving dimension of spousal support for the women managers' careers. Earlier studies of spousal support have been cross-sectional in nature; as far as we know, there are no studies which have captured the dynamics and complexity of how women who have risen to a managerial position think about the spousal support they have (or have not) received in connection with their career throughout their lives. The adopted life-course re-framing provides the advantage that it moves the focus from individuals and their conflicting or enabling role obligations at any one point in time to the dynamic understanding of relationships between roles and among individuals as their lives unfold - over time, in tandem and in particular contexts (M oen \& Sweet, 2004; Savickas et al., 2009).

Secondly, we aim to increase knowledge about gender relations by focusing on what kind of gender order, the institutional and informal social patterns between genders, women managers themselves produce and maintain when discussing their experiences of spousal support for their career. Relying on the approach used by West and Zimmerman (1987), we see that gender relations are created and "done" both as an outcome of and a rationale for various social arrangements and as a means of legitimizing fundamental divisions in society, such as gender order (Gherardi \& Poggio, 2001). So, while talking about the support they get from their spouses for their careers in this study, women managers make choices of how they represent the phenomenon. This can then be seen to have implications in their careers, even if the links between language use and other social practices are best seen as indirect and mediated rather than direct (Fairclough \& W odak, 1997; A Ivesson, 2004).

This article proceeds as follows. A fter presenting our theoretical framework, we will move on to describing our methodological approach. We will then present our empirical results. The final section is in two parts: in it we will discuss our contribution to the field and draw our conclusions.

\section{Theoretical framework}

\section{G ender order and careers}


Connell (1987) uses gender order to refer to a historically constructed pattern of power relations between men and women which, together with femininity and masculinity, can become institutionalized in various levels of society (see also Tienari et al., 2002). Gender order describes the institutional and informal social arrangements that define the complex and changing patterns of gender relations in a particular context (Connell, 1987). Traditional gender order emphasizes the male breadwinner model, which assumes that the man is the primary breadwinner in the family, and the wife is regarded as either a home-based nonmarket carer or a secondary earner (Gherardi, 1995; G herardi \& Poggio, 2001). When women work outside the home, as they do increasingly in many societies, they are expected to pursue professions which are suitable for "real women", who are caretakers (W ood, 2008).

Indeed, "a career" is often written about in organizational and management literature as if it was gender free (Wilson, 1998). Normatively the ideal manager is considered to be a man whose work is his life and whose wife takes care of his household (Kanter, 1977; Acker, 1992), even if she is active in working life herself. This norm of a family man with a wife to manage his household while he gives his full attention to his job is embedded in the concept of career (Nieva, 1985, 175). Thus, according to the traditional gender order, women are more likely to be expected to provide resources for their husbands' careers than receive resources for their own careers and therefore they become positioned in an unequal situation in relation to their husbands. However, this traditional ideal should be seen as a societally embedded construction, something which evolves in time rather than as anything static (Tienari et al., 2002).

As argued in the theory of doing gender (W est \& Zimmerman, 1987), gender is an integral part of any social practice and therefore people cannot not "do gender". Gender order is often taken for granted; for example, women are female and men are male and the former are private and the latter public - organizations can be considered public sites and are therefore seen as male, while the family and household are regarded as private sites and thus seen as female (Gherardi, 1995, 14). This idea often strengthens the assumption of the traditional gender order that the (male) manager is dedicated to his career and has no or few responsibilities for children or family other than bread-winning (A cker, 2006). Such a gender order is not often problematized among managers (Gherardi \& Poggio, 2001; Lämsä \& Sintonen, 2001) or within the wider society (Gherardi, 1995). Moreover, according to Korabik et al. (2008), researchers on the relationship between career and family have often 
ignored families as sites for doing gender, and this is also often the case among management researchers.

In particular, women managers who pursue managerial careers can be seen as producing gender relations in a way which is not in line with traditional gender order assumptions; women managers can be characterized as career-oriented and economically independent of the traditional patriarchal structures of income support from the marriage through their own work life activity (Gatrell, 2007). So even if gender order is typically viewed as self-evident, it is not a given, but rather is done or enacted through social practices such as people's spoken practices, as the social constructionist view emphasizes (Gherardi \& Poggio, 2001; Berger and Luckmann, 1966). This means that gender order is not stable, but is open to change. People can maintain the existing gender order through their manner of speaking or they can challenge the gender order by speaking in other ways.

\section{Spousal support}

In general, social support can be understood in terms of interpersonal transactions that involve emotional concern, instrumental aid, information, or appraisal (House, 1981): emotional concern is associated with sharing life experiences, instrumental aid involves the provision of tangible hel $p$ and services that directly assist a person in need, information refers to the provision of advice, suggestions, and information that a person can use to address problems, and appraisal is linked to the provision of information that is useful for selfevaluation purposes - constructive feedback, affirmation and social comparison. When the discussion of social support is related to spouse and managerial careers, Kanter (1977) proposes that married men are able to invest more resources in their careers than single men because married men's wives, particularly those who are not employed, provide their husbands with additional resources by managing the household and by contributing time and energy to the husbands' careers (Pfeffer \& Ross, 1982).

In studies that have considered explicitly the social support of male spouses for women in the field of career and management, it has been concluded that there is no single form of support from the male spouse for women professionals and managers, but rather this takes a number of different forms (Ezzedeen \& Ritchey, 2008; Friedman \& Greenhaus, 2000; Gordon \& Whelan-Berry, 2004). The most thorough research in the field of spousal support for women managers by Ezzedeen and Ritchey (2008) identified a typology of spousal support 
behaviours: emotional support, help with the household and with family members, career and esteem support, and the husband's career and lifestyle choices. It has been suggested elsewhere that the partners of business professionals provide each other with practical help in the house as well as with the children (behavioural support) and assistance with personal and family or work-related problems (emotional support) (Friedman \& Greenhaus, 2000).

Gordon and Whelan-B erry (2004) found in their research in a healthcare organization that the spouses of female employees most frequently provide support in the areas of earnings and personal financial management (e.g. providing financial security and managing the family finances), and also interpersonal support (e.g. the spouse acts as a sounding board and provides a calming influence). Other studies have suggested that women who receive support from their husbands can better manage the work-family conflict and that spousal support can have an effect on employees' creative performance at work by enhancing their positive mood (R osenbaum \& Cohen, 1999; M adjar et al., 2002).

These positivistic, and often quantitative studies, have tried to define and measure the content or amount of spousal support for enhancing work-wellbeing and career success. $M$ any of these studies have been conducted in the U.S. socio-cultural context, and the focuses of the studies have often been on groups of women working in other than managerial positions. Further, significant part of these studies do not consider gender order, or they take for granted the traditional gender order, suggesting that all managers are family men with wives to manage their household while the man gives his full attention to his job. We aim to fill this research gap not by carrying out another quantitative investigation but by applying a narrative approach with life course re-framing, bringing out the evolving dimension of spousal support for the women managers' careers and using gender order theory to analyse what kind of gender relations women managers create when discussing their experience of spousal support for their career.

\section{M ethodological approach}

\section{Finland as a socio-cultural context}

Lyness and Kropf (2005) and Omair (2010) show that context, for example the national context, has a significant influence on women's careers. This needs to be taken into consideration in research on women's career and family issues. Since narratives always produce contextual and situational knowledge, we need to consider them as a part of the 
wider socio-cultural context which, in this particular study, is Finland. The country is considered to be rather egalitarian (Hausmann et al., 2012). It remained an agrarian society until relatively late, which effectively prevented the development of a strong housewife culture (Lewis, 1993). Thus, for historical reasons the spheres of work and family life did not become as clearly differentiated in Finland as in most other European countries.

Though the institutional discourse of gender equality is commonly accepted in Finland, men continue to have greater access to positions with power, social prestige, higher rewards and resources (Lehto, 2009; Statistics Finland, 2009; Finland Central Chamber of Commerce, 2011) and masculinity is still valued in the top echelons of companies (Tienari et al., 2010). Officially, society has adopted an egalitarian employment mode and the dual-earner model is characteristic of Finnish society. Full-time work for both partners is supported by the extensive system of public childcare, by the tax system in which husband and wife are taxed separately, and by the parental leave system, which gives mothers of young children better opportunities to keep their job and makes easier their return to working life after child bearing. Finland therefore has a high proportion of women in the workforce and Finnish women typically work full-time, even mothers of small children. However, in practice, due to gender role expectations, it is often women who carry the main responsibility for housew ork. (Crompton \& Lyonette, 2006; Piekkola \& Ruuskanen, 2006.)

The modern Finnish woman is typically depicted as having multiple roles (Marakowitz, 1996), as a wife, mother, provider, political participant and opinion leader, all typical features of the superwoman who can heroically cope with all spheres of life (Gordon \& W helan-Berry 2004). However, although they are always characterized as strong rather than weak, powerless and fragile (K atila \& Eriksson, 2011; M arkkola, 2002; Tienari et al., 2005; Lämsä \& Tiensuu, 2002), well-educated Finnish women continually encounter a glass ceiling and are not able to reach the top (Lehto, 2009; Finland Central Chamber of Commerce, 2011). For instance, studies by Hearn et al. (2008) and Välimäki et al. (2009) show that Finnish women's careers are often subordinate to their spouses' careers: women managers usually end up making sacrifices to cope with the reality of having a working husband and a family, and the man's career determines the choices the woman makes in her career.

\section{Research material and analysis}


In this study our research method is based on narrativity, which is taken to be a fundamental form of human understanding through which individuals make sense of the events and people in their lives: in this case women managers making sense of the spousal support they get for their careers (cf. Bruner, 1986, 1991; Polkinghorne, 1988, 1995; Gergen \& Gergen, 1988; Squire, 2008). We understand a narrative in the first place as an account of events occurring over time, thus emphasizing that any narrative has a chronological dimension (Søderberg, 2003). We also understand a narrative to be a person's life story constructed by that person herself (Renza, 1977); this approach will use the experiences, perspectives and ideas through which a person - in our case, a woman manager - narrates and accounts for her career in the larger context of her life (Lämsä \& Hiillos, 2008; Savickas et al., 2009). Finally, we understand narratives to be discursive practices which produce gender (Gherardi \& Poggio, 2001; W est \& Zimmerman, 1987).

To obtain a broad and rich view of the topic, a heterogeneous group of women was studied. Purposeful sampling (Patton, 2002) was used to select women in mid and late career who had sufficient work and life experience to reflect on the topic retrospectively. For the purposes of this study the authors recruited a sample of 25 women by using work contacts and personal networks, mainly from a Finnish executive M BA group and using the contacts of the Finnish Human Resource Managers' A ssociation, HENRY ry. Thus, common features shared by the women were their current top, middle or lower level managerial position and extensive work experience. We conducted 25 interviews with these middle or upper-middle class white women between the ages of 35 and 63 , with a mean age of 45 . The women were working in small, medium and large organizations in the public and private sectors, one third of them being owners of a business. All had a long professional history of between 9 and 38 years and had held managerial positions for between 2 and 35 years. Their educational background varied from secondary level to higher university degrees. All the women managers either had or had had one or more spouses in the course of their careers, and all but one were mothers, mostly of teenage or adult children. The most common number of children was two. M ost of their spouses had an active professional life (working for example as an entrepreneur, employee, expert or manager) and none of the spouses had chosen to have a career as a fulltime house husband, although a few of them had spent some periods of time at home.

The interviews were carried out face to face by the authors in a quiet conference room or office reserved for this purpose; they were recorded and then transcribed word for word. The 
interviews were conducted in Finnish, so all the quotations presented in this article are translations. They followed a semi-structured interview guide covering the successive phases of the woman's career and family life up to the present, all following the same interview method and content. The interview questions were posed in such a way that the women could easily describe their career and family experiences in their own words (A tkinson, 1998). The interviews lasted between one and two hours. Each woman was assigned a number from 1 to 25 , which is used later on in this article to refer to a particular manager.

To process our research material we used a dual-phase analysis: first we used content analysis (K rippendorf, 1980) to interpret the different forms of spousal support, and then in the second phase we adopted the idea of a story line from Gergen and Gergen (1988) to examine the evaluative shifts in the perceived spousal support throughout the women's careers. Gergen and Gergen state that in narratives we can view the various events as moving through evaluative space. This means that when a woman manager expresses in her narrative a valued outcome, the story line becomes more positive as it refers to happiness and satisfaction in her life and career, while the story line becomes more negative when disappointment and failure are recounted. As a whole, the story line of the narrative told by a woman manager can change in relation to time.

A ccording to Gergen and Gergen (1988), all plots of narratives may be converted to a stable, progressive or regressive linear form with respect to their evaluative shifts over time and in this form can be considered rudimentary bases for other more complex variations, creating narrative forms such as tragedy, comedy, 'happily-ever-after' and romance. Tragedy in this sense contains a regressive story line, and would tell a story of downfall. Comedy and 'happily-ever-after' are the reverse of tragedy, and both are dominated by a progressive story line. The comedy narrative consists of some challenges or problems prior to a happy denouement, and in the 'happily-ever-after' narrative the progressive form is followed by a blissful stable end. The narrative of romance consists of many progressive-regressive phases.

The data analysis was organized in two phases using NV ivo computer software. In the first phase of the analysis we read the data many times to become properly familiar with the research material, and began to analyse all the narratives to identify what spousal support could mean for each of the female managers. The different forms of spousal support in the narratives were categorized following the dichotomy favoured by Friedman and Greenhaus 
(2000) into groups of emotional support and behavioural support, plus a group of others. We further analysed the support, focusing on the target of spousal support, whether the individual, the domestic sphere or the public sphere, and interpreted three main categories: psychosocial support, hands-on support and career assistance. Besides positive spousal support, the research material consistently brought out negative non-support, which led us to add this to our analysis as well.

In the second phase of the analysis we approached the narratives again in order to gain a comprehensive understanding and to capture how the forms of spousal support or lack of it evolved over the course of the woman's career. We did so by comparing and contrasting individual narratives in ways that allowed us to assign them to meaningful groups. This was an iterative process as we went back and forth over the research material to see whether and how the spousal support changed during the woman's career, then compared and assigned particular narratives to appropriate categories based on the women's evaluation of spousal support during their careers. In this phase the narratives were categorized into three preliminary groups: narratives where the women narrated that they had spousal support throughout their career, narratives of a lack of spousal support, and narratives which did not belong in either of these groups. The contents of each of the groups were further scrutinized for differences and similarities, and they were re-examined, remodelled and specified. The fluctuation of spousal support was evaluated even more thoroughly within each particular group of narratives (see Gergen \& Gergen, 1988). A nd finally, after many reformulations and discussions, we formed a final division of the narratives into four groups: harmoniously flourishing spousal support, irrelevant spousal support, quitting deficient spousal support, and inconsistent spousal support.

Taken together, the research process was highly iterative, and we discussed and cooperated intensively during the process. Any disagreements were resolved through discussion and further scrutiny of the empirical material. This all meant that the research material, its nature, the co-production process and the interpretation of the material are multiple, interesting and rich - a typical requirement in qualitative research (B ryman \& B ell, 2003). Since narrating is always somehow socially and culturally situated, and the researcher becomes a co-narrator, also involved in creating meanings, specifically in narrative methods (Riessman, 2003; Alvesson, 2003; Gertsen \& Søderberg, 2010), it has to be noted that we as three individual researchers in each interview had our own social situation with the interviewee and created in 
the interview arena a micro-context for the present study. M oreover, since we are all women researchers, we may well have a relationship to women's information and women's experience that is different from that of men (cf. Lämsä \& Hiillos, 2008). Rather than posing a limitation to the study, we feel that our being women often led to mutual identification with our interviewees and at some points in the process to an exchange of experiences. Riessman (2003) reminds us that the interpretation intended or conceived by the narrator may not al ways be the interpretation made by the audience, which can result in contested meanings. A s three separate researchers with different career backgrounds and ages we formed different insightful audiences in relation to the women in the research set. This enabled us to surface al ternative meanings to point out non-obvious or help in making sense of career.

\section{Findings}

W e first present our interpretation of the women's forms of (non-)spousal support in relation to their careers, and then move on to the fluctuations of the narrated spousal (non-)support during the women's careers.

\section{The forms of (non-)spousal support}

Psychosocial support is constructed by the women as behaviours that provide encouragement, respect and understanding, and support discussion; such behaviours can be by nature explicit or tacit. Psychosocial support is constructed as contributing to careers indirectly by providing women with personal resources that are valuable in the work context. The focus is thus on the women as individuals. Explicit psychosocial support is narrated by the women with reference to the spouse's discussing things and listening to his wife about decisions concerning his wife's career opportunities, dilemmas and challenges. The spouse is depicted as inspiring and encouraging the woman to new achievements, professional development and orientation to new career paths. A dditionally, he is constructed as having an understanding of the requirements and challenges of women's career ambitions. The husband is said to admire and value his spouse as a person and her success as a manager. Similar results were also found by Ezzedeen and Ritchey (2008) and Friedman and Greenhaus (2000).

In the tacit psychosocial support mode, the spouse's role is constructed as more passive, but still as providing important support. The spouse is viewed as acting in the background to 
provide a secure basis for the woman's career. He is constructed as a partner who provides silent support for his wife's work and has a firm belief in what she is doing. He is valued for giving the woman enough space and freedom to advance in her career. In general, in the context of this form of support, the women feel that it is much more enriching to have a spouse than to be a single woman. In this form of support the spouse is said to understand the logic of business leadership as well as the demands of combining a managerial position and family life. The relationship between the spouses is constructed as that of a team that works smoothly together.

Hands-on support is a form of support which is constructed as contributing to a career indirectly, as in the case of psychosocial support. However, it is constructed as having a different quality and different target of support from psychosocial support. Hands-on support is narrated as help provided by the spouse in household tasks and taking care of children. Thus, it is constructed as practical in nature and targeted at family life. The women say that it makes it easier for them to combine career and family, and it releases energy that they can fully commit to their career. Hands-on support is narrated as particularly welcome when the women have time-consuming activities at work, such as management development events and work trips, or in situations where the children need a lot of care and attention.

Career assistance is support which is constructed as directly targeted at the career, and thus it can be clearly distinguished from psychosocial and hands-on support. Firstly, it is narrated as referring to a spouse's practical career support, such as his being present at work-related events and providing practical assistance with technical career issues like helping with CV s or job applications. Secondly, this form of support can be constructed as instrumental, often financial in nature. The husband is narrated as providing financial security for the woman to start her own business and organizing a comfortable living and working environment. Moreover, the spouse is constructed as helping with valuable networking. Thirdly, the spouse's own career choices are narrated as assisting the women's careers. Thus the husband is said to make compromises in his career by taking parental leave, working shorter days, having flexible work arrangements and making a conscious decision to be in second place in terms of career development.

Beside these three forms of spousal support, non-support is also clearly constructed in the narratives of the women managers. The women managers said that they had not received the 
support which would have been helpful to advance in their career or had not had the opportunity to develop in working life. Lack of support is constructed especially in relation to career decision-making and the spouse being unappreciative of the woman's work. Instead of the woman's career aspirations and achievements being supported by their spouse, they were belittled. Lack of support is also constructed in relation to housework and taking care of children, with the spouse allegedly leaving domestic work to the woman. The spouse is narrated as believing that the woman's proper place is at home raising the children and taking care of the housework, not investing in working life and a successful career. It was also mentioned that the woman's high salary and career success is difficult for the spouse to accept. Table 1 summarizes the forms of spousal (non-)support.

[Table 1 about here]

\section{Narratives of evolving spousal support}

Harmoniously flourishing spousal support

Different forms of spousal support are narrated in this group of narratives as flourishing throughout the woman's entire career. A Itogether fourteen narratives (from women Nos. 1, 2, $4,6,11,12,15,17,18,19,20,23,24,25)$ fit into this group. The tone in this group of narratives is optimistic and bright. Any shift in the narration is progressive in nature and resembles the story line of the 'happily-ever-after' according to Gergen and Gergen (1988). Support is described as developing in line with the woman's career and is presented in a particular ordered sequence from practical hands-on support to psychosocial support. Spouses are also said to provide career assistance to the women whenever required, throughout their career. In the narratives an important trigger for the change from hands-on to psychosocial support is the children's growing up, when the need for the spouse's hands-on support is constructed as decreasing. This is constructed as deflecting the spouse's energy into psychosocial support so long as he accepts or feels comfortable with the woman's career advancement and success. Thinking of her career, the woman manager articulates such a change in the quality of spousal support as making possible a happy outcome - pursuing a successful career and having a rewarding family life. Woman manager N 0.19 describes how her husband adjusted to her career and took responsibility for the children as well: "And my husband really has sort of wanted to give way, that what is it to me if the children have got 
ill, which in fact they haven't done often, so he's almost wanted to stay and look after them all the time." A nother woman manager (25) describes how discussions with her husband have become much deeper than they were in the early days of their relationship. She put it as follows: "And if I compare [ the spousal support] to what it was 10 years ago when we had just met, in the beginning, well we do speak nowadays more about work-related stuff [with my husband], and also argue with each other and discuss things and."

The woman links the experiences of her career together with spousal support in such a way that a positive direction characterizes both fields and their movement over time. The end point in these narratives is weighted by the woman with value and satisfaction. A typical illustration from the narratives of this group is presented by woman manager N 0.24 :

\begin{abstract}
Yes, that's definitely the most important thing, because he's created in a way sort of the framework and what's around it, and it's been easy for me, of course it depends on what each person is like and I've had a genuine interest and I' $m$ that sort of interested and of course I sort of anyway want to do things and I' $m$ work orientated. But really without him I certainly wouldn't be here, I'd be somewhere else altogether. So he's in that way sort of encouraged and supported and helped, as much as he could. And then, when I've sometimes had the sort of day that, I mean, that I've been hit by despair or some sort of doubt like that, then definitely he has sort of driven that sort of despair away quite quickly and said, come on, don't worry. He's you know the best person to sound out ideas on and that sort of mentor. And, I laughed recently about something we were talking about and he said that that's how it should be... that yes really, that I've got to say that he's the most important sort of supporting factor in the world. That I'm here. And I've made this sort of career.
\end{abstract}

(from interview with woman manager No.24)

In this story line the woman manager challenges the traditional gender order and constructs the gender relation between the spouses so that the husband and wife are defined as equal and as becoming a genuine team in the family: they share a common interest and ambition to guarantee the welfare of the whole family as well as the career of the woman. In other words, the spouses are positioned in this story line as cooperative actors, and the changing nature of the spousal support from the husband and the equal type of gender order are constructed by the woman as being crucial for her pursuit of a successful career alongside having a happy family life. 
Irrelevant spousal support

In this group of narratives no crucial support is narrated as being received or even asked for from the spouse; rather the woman constructs support from her spouse as irrelevant to her career. Peculiar to these narratives is that the woman says that she pursues and manages her career entirely on her own. She narrates herself as a very career-oriented person, and financially very much independent of her husband's income. Three narratives (from women Nos. $8,9,16$ ) belong in this group. The tone in this group of narratives is positive or neutral, but remains stable throughout the career. Compared to the 'happily-ever-after' story line, in which the narration is progressive, the narration here is stable. Gergen and Gergen (1988) propose that stability in a narrative can be pitched at any level in evaluative terms, either continuously positive or continuously negative. Two managers $(9 \& 16)$ clearly stated that they did not need spousal support to manage or be successful in their careers. "Satisfaction and happiness in life emerge and arise from yourself, not from your partner", one of them (9) emphasized.

Woman manager No.8 explained that she had had a serious relationship for only a short period in her life and had been able successfully to pursue a career and bring up her children on her own. By making a conscious decision to stay alone after the relationship she prioritized the welfare of the children and made all her career decisions thinking of them and their happiness. This is illustrated as follows:

\footnotetext{
“I: When you've been alone with the children it hasn't been in any way a conscious choice?

W: It was a conscious choice that I kicked this man out. It was fully conscious. And on the other hand it has been a conscious choice not to get a new one."
}

(from interview with woman manager No.8)

In this story line the topic of the spouse or his support is not very prominent, and when it is brought up by the woman manager she claims that she needed no or very little support from him. She constructs herself as able and responsible for her life, both career and children, and in her view the spouse is not integral to her plans, or is only loosely connected to her life management in general. One of the managers (16) related that she had encountered social pressures as a business owner and a single woman and for this reason got married for a while, 
but she soon decided to raise her child alone, and has managed at the same time to pursue a successful career. She made her point by saying: "But I'm not going to have a bad one (man), if I don't want to, I'm not going to be forced to live with anyone."

By emphasizing herself as independent from the spouse, the woman manager constructs herself as self-managing in different arenas of her life and she leaves untouched the traditional gender order pattern al together in these narratives. D efining herself as a strong and capable person who manages the career-family relationship by herself is a rather typical way for Finnish women managers to describe themselves (Lämsä \& Tiensuu, 2002; Katila \& Eriksson, 2011). However, this narration is not unproblematic, since Finnish women managers are often faced with the consequences of carrying a double-burden: not only do they work and have a career, but they also have responsibility for the family and housework (Piekkola \& Ruuskanen, 2006; V anhala, 2005; Jamieson, 1995).

Quitting deficient spousal support

A common feature in this group of narratives is that only minimal support from the husband is narrated as being available. Five narratives from the women (Nos. 5, 7, 10, 13, 21) belong to this group. According to these narratives the spouse might sometimes provide some practical hands-on support and even in some cases some career assistance - usually when urgently needed and specifically asked for - but the support given is hardly ever psychosocial in nature, and so it is constructed as deficient. The tone in this group of narratives ranges from negative to positive and the story line can be interpreted as shifting, like that of a romance, according to Gergen and Gergen (1988). This involves a series of events and issues which the protagonist experiences as challenges and over which, through a series of struggles, she emerges victorious (ibid.). Thus the ending of these narratives is represented as positive, even happy. A $n$ illustration from the narratives of this group is presented by woman manager (7) as follows:

\footnotetext{
"W: And then there was this hard phase, well he was unemployed, and he played tennis all day long and went for a coffee with the boys and so on, I always arranged the babysitters and everything. It was terrible, that like that, he didn't support me at all. He didn't give any kind of support. However he was, well he also had some business education whereas I don't have any business training whatsoever, so I
} 
assumed that he would have helped me for example with well those accounting matters, since he at least after all understood something of it...

I: Can you yourself imagine why he treated you like this?

W: Well now, well now we are much better friends than we were when we were married, especially at the end, but he said that I am so strong. That I'm too strong, that I don't need anyone. I said that yeah, may be, you evolve, grow some hair on your chest when you ask for help for long enough and don't get any (support).

I: Well, how about your present partner or spouse, how does he feel about you working?

W: Well he is very supportive. So he is very different because of that, and that is why he is still around, I guess."

(from interview with woman manager No.7)

The major difference between this group of narratives and narratives of irrelevant spousal support is that in this case the women clearly articulate particular and shifting expectations for spousal support during their careers and marriage, while the women in the latter group mention it only occasionally and when they do, they show that they only expect either minimal support or none at all.

Following the traditional gender order pattern in relation between the spouses is constructed as an initial challenge for women managers. To overcome this challenge and to achieve the desired end point, success in her career and the proper care of the family, she is narrated as managing the situation by working hard in both the domestic and public spheres of life carrying a double burden. In other words, the woman does not narrate that she wants to change the unequal gender relation that she experiences with her spouse by challenging the traditional gender order pattern, but rather that she accepts it.

A second challenge is constructed at a later stage in her career, when the children have grown up. Since only a little hands-on support is said by the women to be necessary in this phase, it is constructed as preferable for spouses to move in the direction of psychosocial support, which is viewed as important by the women. Little or no support is narrated as being available, so the women become fed up with their husbands' negative attitude and minimal support, and decide to resolve the situation by getting a divorce. Though divorce is narrated in the short term as a negative episode, in the long run it is viewed as positive from the career point of view, and thus the end point - a successful career and satisfying life in general - is given a positive value. One manager (5) described her divorce as an empowering experience: "I would never have had the chance to fulfil myself in this way if I was still married. No. It 
tied me down too much to it... So that was certainly a big change, that I was able to go and start doing these things (entrepreneurship)." So we see that although she narrated divorce as baffling at that time, but after recovering, she made a significant successful change in her career, leaving behind a stable position in a large organization and entering a whole new area of entrepreneurship.

Though in the early phase of her career she had adapted to the traditional gender order, in the long run she does not narrate such an adaptive way of acting as desirable. The woman constructs her male partner as yearning for the traditional gender order, but she herself is not depicted as being satisfied with this. Challenging and questioning the gender order is constructed as confusing for both the career and the family of the woman manager. The solution to the problem is narrated as being through divorce. This means that even if the traditional gender order is challenged and questioned, it is ultimately left the same. However, through divorce the unsatisfactory gender order pattern is said to be overcome, and the situation is narrated as improved.

Inconsistent spousal support

In this group of narratives the woman manager constructs support from her husband, especially hands-on support and some career assistance. However, this support is narrated as being inconsistent: one day the spouse might be supportive, another day unsupportive. Three of the narratives have such characteristics (Nos. 3, 14, 22). The tone of these narratives is confused and disappointed, and the typical story line involves some characteristics peculiar to tragedy, according to Gergen and Gergen (1988). Tragedy consists of challenges which the major protagonist is unable to overcome in his or her pursuit of the desired end point (ibid.). Although the woman's narration in relation to her career is progressive in nature, highlighting that an important end point, namely success in the career, is coming closer or has even been reached, the narration incorporates dissatisfaction with spousal support during the career. The spouse's hands-on support in the domestic sphere and some practical career assistance are constructed as being valuable, especially in the earlier phases of the career while the children are small. However, a desired change in the quality of spousal support in the direction of psychosocial support in the later phase of the career is articulated as not happening. Unlike the 'happily-ever-after' story line, where the husband's support is narrated as evolving in the 
desired way, the support here remains the same and is evaluated by the woman as regressive over time.

One of the managers (3) explained that in the past her husband had helped and supported her specifically by taking care of the children, but that more recently he had not approved of her long working hours. Nor could he understand and discuss the many demands of the woman's work that caused her problems, and this led her to question her career choices as well as her future career aspirations. One woman manager (14) said that she and her spouse were like rivals. On the one hand her husband supported her, for example, advising her about getting work-related training, but on the other hand when it came to actual status and advancement he did not offer any psychosocial support such as feeling proud of her achievements in her career, which would have been important to her. She felt confused about this. A $n$ illustration from her narrative highlights the inconsistent nature of the support in this group of narratives:

\footnotetext{
"W: Well, it is a two-edged thing. My husband is very good at supporting and at encouraging and at challenging me, and [he is] happy that I take part in this training, and he sort of wants me to, he is the kind of guy who will just go and do something and he goes and is brave and moves on and takes responsibility. F ull of energy. When I was in this human resources world, I didn't get much respect and somehow [I was] even belittled, that what I was doing wasn't really work at all.

I: Your partner doesn't think very highly of this human sector work. W: Or actually the work that I do. I was like, well I don't know, whether my role is in that sector, are we somehow a bit like competitors. Then on the other hand, when thinking of development and so on, then there's full support."
}

(from interview with woman manager No.14)

A nother of the women (22) narrated that she did not like her husband being at home with the children and taking care of the domestic side of things while she was working. These changes in traditional gender roles in the context of work and family were problematic for her. She said: "I wouldn't wish anything like this on anybody, a lot of work, and small children and a husband at home. And the pressure from the people around you, it isn't sympathetic." suggesting that she would not recommend other women to have a stay-at-home husband, although her husband did pursue his career to some extent by working from home. 
In this group of narratives there is no resolution of the problem of unchanging and unsatisfactory spousal support, neither through divorce as in the story line of romance, nor through the cooperative and maturing process of change that happens in the 'happily-everafter' story line. Thus, the valued end, career success together with the desired spousal support, is still constructed as an open question. The gender relation between the spouses is constructed as if looking for a way between the equal and traditional gender order patterns, and this is described as problematic from both the career and family perspectives of the women managers. Table 2 summarizes narratives of evolving spousal support in the course of women managers' careers.

[Table 2 about here]

\section{Discussion}

The aim of this study was to investigate women managers' careers and families by studying empirically how the women managers experience the support given by their male partners from the perspective of their career. In addition we were interested in what kind of gender relations women managers create when discussing their experiences of spousal support for their career. We used the concept of gender order to analyse the gender relations between the woman manager and her male spouse. As a result, this study makes two important contributions: Firstly, while previous studies on spousal support have paid little attention to evolving dimension of spousal support for women managers' careers, we have found that spousal support for careers was constructed as varying and ambiguous by Finnish women managers: flourishing, irrelevant, deficient and inconsistent. The findings of this research are in line with the suggestion made by Ezzedeen and Ritchey (2008) that women managers find spousal support to be a multifaceted phenomenon. Our findings extends to previous studies that relationship between career and family, specifically the relationship between the woman manager's career and the spousal support she gets, is experienced by women as stable; rather, our findings support the view that this relationship is mostly equivocal, dynamic and changing.

M oreover, from the results of this study it has become apparent that spousal non-support is also experienced by women managers - a point that, as far as we know, has not been analysed explicitly in previous studies about women managers' careers. This is a topic worth 
further research in the future. Though our aim in this study was to capture how spousal support is constructed as evolving in line with the careers of women who have risen to a managerial position, it has to be noted that we did not research the topic by using a longitudinal data set. These narratives, which all address woman managers' life courses, were constructed in research situations creating situation-located knowledge (cf. Ricoeur, 1984). In general, a longitudinal research approach would be valuable in studying careers, but in practice it is difficult to conduct since such research requires decades.

Though it has been noted that gender relations in family sites can act as an organizing principle which provides resources and limitations for a woman manager's career (Gherardi, 1995; K immell, 2000; K orabik et al., 2008), the analysis of gender order in relation to women managers' careers and spousal support has been rare. Thus, the second main contribution of this study was to use gender order (Connell, 1987) to analyse gender relations between the woman manager and her spouse. Usually when gender is done in families (West $\&$ Zimmerman, 1987), the traditional gender order stresses that the man is dedicated to a career and has no responsibility for children or family other than breadwinning, and that the woman is responsible for family and household (Gherardi, 1995; Acker, 2006). By studying the narratives of women managers, who can be seen as acting contrary to traditional gender order assumptions (Gatrell, 2007), we identified four different groups of narratives which followed four different storylines and illustrated the change of spousal support for the woman manager's career from the point of view of gender order: happily-ever-after, stable, romance, and tragedy. In the second group of narratives, the storyline was stable and left the traditional gender order untouched. In the other groups the storylines were shifting, and the gender order between the couple is clearly brought out into the open and discussed, making it possible for the traditional order to be challenged. However, as shown in this paper, the traditional gender order was said to be challenged only in the happily-ever-after story line. In the story lines of romance and tragedy there was discussion of the traditional gender order but it remained vague and unchallenged.

In this study the most positive narratives were those in which spousal support was constructed as harmoniously flourishing and the traditional gender order was challenged by the women managers, who asked for more flexibility and fluidity in gender relations with their spouse. We think that there are three important practical implications from this for women managers and their spouses. First of all, the spouse who is willing to take care of the 
family and provide needed psychosocial support is also breaking the historical masculine gender norm by expanding his role into the family domain. Simultaneously, he is approving and supporting his female spouse's success in a traditionally male sphere - a managerial career. In addition to this, the woman manager for her part is willing to let her spouse act in her traditional sphere. Daly et al. (2008) state that given the traditional assumption that women have primary control over the family and household, women are often considered to be gatekeepers on domestic issues - a role that the woman must be willing to give up. Lastly, the women managers in this study articulated the view that a change over the years from practical hands-on support to psychosocial support was beneficial and satisfactory: ideally, over the years, the husband's support is not fixed in one particular form but rather is dynamic and changing. People's life and career situations are complex and varied, and we see that ideally there is a close fit between spousal support and the women managers' expectations and needs; but particularly crucial is to be aware that these expectations and needs can be different at different times and places (Gordon \& Whelan-B erry, 2004).

Contrary to the storyline discussed above, in the narratives in which spousal support was constructed as irrelevant and the gender order was left untouched, the woman manager produced herself as bravely taking on both the conventional private feminine role and the public masculine role. She successfully manages both her career and her family on her own; the Finnish woman manager is a heroic superwoman - an idea already reported in some studies on women managers and professionals in the Finnish context (e.g. Lämsä \& Tiensuu, 2002; Katila \& Eriksson, 2011): the woman is strong, capable and enduring in the intersection of work and family. By emphasising the woman's strength this story line makes it unnecessary to challenge the traditional gender order in gender relations between the spouses, but by constructing gender as irrelevant it leaves the traditional gender order untouched and unquestioned, making it difficult to notice and change. This is in line with the idea put forward by Martin (2003) that women often do not challenge the traditional gender order since to do so is perceived as 'rocking the boat'. Thus, we see that the women managers in this group, while discursively producing the superwoman pattern, may contribute through such narrations to the production and maintenance of unequal relationships between the genders in the intersection of work and family - albeit unintentionally. In this study we have shown that gender order is critical for our understanding of the nature of spousal support, and gender relations can operate in various ways in the family site with both positive and negative implications for women managers' careers and families (West and Zimmerman, 1987; 
Korabik et al., 2008). Families as sites of doing gender would offer worthwhile research topics in the field of careers and management.

\section{Conclusion}

The final conclusion of this study is that a male spouse who is constructed as willing to break the traditional gender order (Wood, 2008; Connell, 1987; Gherardi, 1995) and provide changing forms of support, from hands-on support to psychosocial support, is constructed in many cases as having a positive influence on the career of his woman manager spouse. Further, we conclude that when the woman manager constructs the gender order pattern between the spouses as equal and dynamic, she feels that it has many positive outcomes for her career and family life. A bove all, it can be said that when the gender order pattern is openly discussed by the woman manager and her spouse, it can then be analysed, challenged and changed if needed. When the gender order is left untouched and unchallenged, it may unintentionally maintain and produce unequal power relations between spouses in the career and family context.

Given the importance of both career and family in the lives of many women managers and the overlapping of these spheres in their lives (Duxbury \& Higgins, 2005; Guillaume \& Pochic, 2009), we suggest that management development activities and career practices such as, for example, career counselling, mentoring, coaching, and international job assignments should consider women's (as well as men's) career choices and decisions within a broader context, especially family life. Organizations should pay more attention to the changing nature of people's careers and families in the life course and better adapt their practices to fit the varying stages of life. 


\section{R eferences}

A cker, J. (1992). Hierarchies, jobs, bodies: a theory of gendered organizations. Gender $\&$ Society, 4(2), 139-158.

A cker, J. (2006). Inequality regimes: Gender, class, and race in organisations. Gender and Society, 20(4), 441-464.

Alvesson, M. (2003). Beyond neopositivists, romantics and localists: A reflexive approach to interviews in organizational research. Academy of Management Review, 28(1), 13-33.

Alvesson, M. (2004). Organizational culture and discourse. In D. Grant, C. Hardy, C. Oswick $\&$ L. Putnam (Eds.), The Sage handbook of organizational discourse (pp. 317-336). London: Sage.

A tkinson, R. (1998). The life story interview. Thousand Oaks, CA : Sage.

Berger, P.L., \& Luckmann, T. (1966). The social construction of reality. N ew Y ork: Doubleday.

Blair-Loy, M. (2003). Competing devotions: career and family among women executives. Cambridge, M A : Harvard U niversity Press.

B runer, J. (1986). Actual minds, possible worlds. Cambridge, M A : Harvard University Press.

B runer, J. (1991). The narrative construction of reality. C ritical Inquiry, 18(1), 1-21.

B runer, J. (2004). Life as a narrative. Social Research, 71(3), 691-710.

B ryman, A. \& B ell, E. (2003). Business research methods. Oxford: Oxford U niversity Press.

Bujold, C. (2004). Constructing career through narrative. J ournal of Vocational Behavior, 64(3), 470-484.

Chase, S.E. (2005). N arrative inquiry: multiple lenses, approaches, voices. In N.K. Denzin \& Y.S. Lincoln (Eds.), The Sage handbook of qualitative research (pp. 615-679). Thousand Oaks, CA: Sage.

Cohen, L. (2006). Remembrance of things past: Cultural processes and practice in the analysis of career stories. J ournal of Vocational Behavior, 69(2), 189-201.

Cohen, L., Duberley, J \& \& M allon, M. (2004). Social constructionism in the study of career: Accessing the parts that other approaches can not reach. J ournal of Vocational Behavior, 64(3), 407-422.

Connell, R.W . (1987). Gender and power. Stanfrod, CA : Stanford University Press.

Crompton, R., \& Lyonette, C. (2006).W ork-life 'balance' in Europe. Acta Sociologica, 49(4), 379-393. 
Daly, K., A shbourne, L., \& Hawkins, L. (2008). W ork-life issues for fathers. In K. Korabik, D.S. Lero, \& D.L. W hitehead (Eds.), Handbook of work-family integration (pp. 249-264). London: A cademic Press.

Duxbury, L., \& Higgins, C. (2005). Work-life challenges professional women face in pursuing careers. In R.J. Burke, \& M.C. Mattis (Eds.), Supporting women's career advancement (pp. 174-209). Cheltenham: Edward Elgar.

Ezzedeen, S.R., \& Ritchey, K.G. (2008). The man behind the woman: A qualitative study of the spousal support received and valued by executive women. J ournal of Family Issues, 29(9), 1107-1135.

Ezzedeen, S.R., \& Ritchey, K.G. (2009). Career advancement and family balance strategies of executive women. Gender in M anagement: An International J ournal, 24(6), 388-411.

Fairclough, N., \& Wodak, R. (1997). Critical discourse analysis. In T.A. Dijk (Eds.), Discourse as social interaction, discourse studies: A multidisciplinary introduction, Vol. 2 (pp. 258-284). London: Sage.

Finland Central Chamber of Commerce (2011). M iehet johtavat pörssiyhtiöiden liiketoimintoja - naiset päätyvät tukitoimiin. Available at: http://www.keskuskauppakamari.fi// ulkaisut/M uut-julkaisut/M iehet-johtavat-porssiyhtioidenliiketoimintoja-naiset-paatyvat-tukitoimintoihin.

Friedman, S.D., \& Greenhaus, J.H. (2002). Work and family - allies or enemies? What happens when business professions confront life choices. Oxford: Oxford U niversity Press.

Gatrell, C. (2007). W hose child is it anyway? The negotiation of paternal entitlements within marriage. The Sociological Review, 55(2), 352-371.

Gergen, K.J ., \& Gergen, M .M . (1988). Narrative and the self as relationship. In L. B erkowitz (Eds.), Advances in experimental social psychology (pp. 17-56). San Diego, CA: A cademic Press.

Gertsen, M.C. \& Søderberg, A-M . (2010). Expatriate stories about cultural encounters - A narrative approach to cultural learning processes in multinational companies. Scandinavian J ournal of Management, 26(3), 248-257.

Gherardi, S. (1995). Gender, symbolism and organizational cultures. London: Sage.

Gherardi, S., \& Poggio, B. (2001). Creating and recreating gender order in organizations. J ournal of World Business, 36(3), 245-59.

Gordon, J.R. \& W helan-Berry, K.S. (2004). It takes two to tango: an empirical study of perceived spousal/partner support for working women. Women in Management Review, 19(5), 260-273.

Greenhaus, J.H. \& Powell, G.N. (2006). W hen work and family are allies: A theory of workfamily enrichment. Academy of M anagement Review, 31(1), 72-92. 
Greenhaus, J.H., \& Singh, R. (2004). Family-work relationships. In C.D. Spielberger (Eds.), Encyclopedia of applied psychology (pp.687-698). San Diego, CA : Elsevier.

Greenhaus, J.H., \& Foley, S. (2007). The Intersection of work and family lives. In H. Gunz, $\&$ M. Peiperl (Eds.), Handbook of career Studies (pp. 131-152). Thousand Oaks, CA : Sage.

Guillaume, C., \& Pochic, S. (2009). What would you sacrifice? A ccess to top management and the work-life balance. Gender, Work and Organization, 16(1), 14-36.

Haussmann, R., Tyson, L.D., \& Zahidi, S. (2012). Global gender gap report 2012. Geneva: World Economic Forum.

Hearn, J., Jyrkinen, M., Piekkari, R., \& Oinonen, E. (2008). Women home and away: transnational work and gender relations. J ournal of Business E thics, 83(1), 41-54.

House, G.S. (1981). Work stress and social support. R eading, M A : A ddison-W esley.

Jamieson, K. (1995). Beyond the double bind: Woman and leadership. New Y ork: Oxford U niversity Press.

K anter, R. M . (1977). M en and women of the corporation. N ew Y ork: B asic Books.

Katila, S., \& Eriksson, P. (2013). He is a firm, strong-minded and empowering leader, but is she? Gendered positioning of female and male CEOs. Gender, Work and Organization, 20(1), 71-84.

Katila, S., \& M eriläinen, S. (1999). A serious researcher or just another nice girl? Doing gender in a male-dominated scientific community. Gender, Work and Organization, 6(3), 163-173.

Kimmell, M. S. (2000). The gendered society. N ew Y ork: Oxford U niversity Press.

K orabik, K., M cElwain, A., \& Chappell, D.B. (2008). Integrating gender-related issues into research on work and family. In K. Korabik, D.S. Lero, \& D.L. Whitehead (Eds.), Handbook of work-family integration (pp. 215-232). London: A cademic Press.

K rippendorf, K . (1980). Content analysis: An introduction to its methodology. Beverly Hills, CA: Sage.

Lämsä, A-M ., \& Hiillos, M . (2008). Career counselling for women managers at mid-career: Developing an autobiographical approach. G ender in M anagement: An International J ournal. 23(6), 395-408.

Lämsä, A-M ., \& Sintonen, T. (2001). A discursive approach to understanding women leaders in working life. J ournal of Business Ethics, 34(3-4), 255-267.

Lämsä, A., \& Tiensuu, T. (2002). Representations of the woman leader in Finnish business media articles. Business E thics: A European Review, 11(4), 355-366.

Lehto, A-M . (2009). N aiset val taavat esimiespaikkoja. H yvinvointikatsaus, 3, 14-19. 
Lewis, J. (1993). Women and social policies in Europe. A ldershot: Edward Elgar.

Lyness, K.S., \& Kropf, M.B. (2005). The relationships of national gender equality and organizational support with work-family balance: A study of European managers. Human Relations, 58(1), 33-40.

Madjar, N., Oldham, G.R., \& Pratt, M.G. (2002). There's no place like home? The contributions of work and nonwork creativity support to employees' creative performance. Academy of M anagement J ournal, 45(4), 757-767.

M äkelä, L., Känsälä, M . \& Suutari, V . (2011). The roles of expatriates' spouses among dual career couples. Cross Cultural M anagement: An International J ournal, 18(2), 185-197.

Marakowitz, E. (1996). Gender and national identity in Finland: An exploration into women'spolitical agency. Women's Studies International F orum, 19(1-2), 55-63.

Markkola, P. (2002). Vahva nainen ja kansallinen historia. In T. Gordon (Eds.) Suomineitonen hei! Kansallisuuden sukupuoli (pp. 75-90). Tampere: V astapaino.

M artin, P.Y . (2003). 'Said and done' versus 'saying and doing': gendered practices/practising gender at work. Gender and society, 17(3), 342-366.

Moen, P. \& Sweet, S. (2004). From 'work-family' to 'flexible careers' A life course reframing. Community, Work \& F amily, 7(2), 209-226.

Nieva, V.F. (1985). W ork and family linkages. In L. Larwood, A.H. Stromberg, \& B.A. Gutek (Eds.), Women and work, vol.1 (pp. 162-190). B everly Hills, CA : Sage.

Omair, K. (2010). Typology of career development for A rab women managers in the United A rab Emirates. Career D evelopment International, 15(2), 121-143.

O'Neil, D.A. \& Bilimoria, D. (2005). Women's career development phases. Career Development International, 10(3), 168-189.

Patton, M .Q. (2002). Qualitative research and evaluation methods. (3rd ed.). Thousand Oaks, CA: Sage.

Pfeffer, J. \& Ross, J. (1982). The effects of marriage and a working wife on occupational and occupational and wage attainment. Administrative Science Q uarterly, 27(1), 66-80.

Piekkola, H., \& Ruuskanen, O-P. (2006). Work and time use across life cycle - mothers and ageing workers. Reports of the M inistry of Social A ffairs and Health Finland 2006: 73.

Polkinghorne, D.E. (1988). Narrative knowing and the human sciences. Albany, NY: State University of $\mathrm{N}$ ew $\mathrm{Y}$ ork Press.

Polkinghorne, D.E. (1995). Narrative configuration in qualitative analysis. In J.A. Hatch, \& R. W isniewski (Eds.), Life history and narrative (pp. 5-23). London: Falmer Press. 
Powell, G.N., \& Mainiero, L.A. (1992). Cross-Currents in the river of the time: Conceptualizing the complexities of women's careers. J ournal of Management, 18(2), 215237.

Renza, L.A. (1977). The veto of the imagination: a theory of autobiography. New Literary History, 9, 1-26.

Ricoeur, P. (1984). Time and narrative, Vol. 1. Chicago: University of Chicago Press.

Riessman, C.K. (2003). A nalysis of personal narratives. In J.A. Holstein \& F.F. Gubrium (Eds.), Inside intervieweing: new lenses, new concerns (pp. 331-346). Thousand Oaks, CA: Sage.

Rosenbaum, M. \& Cohen, E. (1999). Equalitarian marriages, spousal support, resourcefulness, and psychological distress among Israeli working women. Journal of Vocational Behavior, 54(1), 102-113.

Rothbard, N.P., Phillips, K.W., \& Dumas, T.L. (2005). Managing multiple roles: Workfamily policies and individuals' desires for segmentation. Organization Science, 16(3), 243258.

Ruderman, M .N., Ohlott, P.J ., Panzer, K ., \& K ing, S.N. (2002). Benefits of multiple roles for managerial women. Academy of Management J ournal, 45(2), 369-386.

Savickas, M . L., N ota, L., Rossier, J., Dauwalder, J -P, Duarte, M .E , Guichard, J ., O resi, S., V an Esbroeck, R. \& V an V ianen, A.E.M . (2009). Life designing: A paradigm for career construction in the 21st century. J ournal of Vocational Behavior, 75(3), 239-250.

Squire, C. (2008). Experience-centred and culturally-oriented approaches to narrative. In M. Andrews, C. Squire, \& M. Tamboukou (Eds.), Doing narrative research (pp.41-63). Thousand Oaks, CA : Sage.

Simpson, R. (1998). Presenteeism, power and organizational change: Long hours as a career barrier and the impact on the working lives of women managers. British Journal of M anagement, 9, S37-S50.

Statistics Finland (2009). Vallan tasa-arvoa Sukupuolten tasa-arvo. Helsinki: Statistics Finland.

Søderberg, A. (2003). Sensegiving and sensemaking in an integration process: A narrative approach to the study of an international acquisition. In B. Czarniawska, \& P. Gagliardi (Eds.), Narratives we organize by (pp.3-35). Philadelphia: John Benjamins Publishing Company.

Tienari, J., Quack, S., \& Theobald, H. (2002). Organizational reforms, 'Ideal W orkers' and gender orders: A cross-societal comparison, Organization studies, 23(2), 249-279.

Tienari, J., Søderberg, A-M., Holgersson, C., \& V aara, E. (2005). Gender and national identity constructions in the cross-border merger context. Gender, Work \& Organization, 12(3), 217-41. 
Tienari, J ., V aara, E., \& M eriläinen, S. (2010). Becoming an international man: Top manager masculinities in the making of a multinational corporation. Equality, Diversity and Inclusion: An International J ournal, 29(1), 38-52.

Välimäki, S., Lämsä, A -M ., \& Hiillos, M . (2009). The spouse of the female manager: Role and influence on the woman's career. Gender in Management: An International J ournal, 24(8), 596-614.

V anhala, S. (2005). Huono omatunto: naisjohtaja perheen, työn ja uran törmäyskurssilla. Työ ja ihminen, 19(2), 199-214.

West, C., \& Fenstermaker, S. (1995). Doing difference. Gender \& Society, 9(1), 8-37.

West, C., \& Zimmerman, D.H. (1987). Doing gender. Gender and Society, 1(2), 125-151.

White, B. (1995). The career development of successful women. Women in Management Review, 10(3), 4-15.

Wilson, E.M . (1998). Gendered career paths. Personnel Review, 27(5), 396-411.

Wood, G. (2008). Gender stereotypical attitudes: Past, present and future influences on women's career advancement. E qual O pportunities International, 27(7), 613-628.

Y oung, R. A \& \& Collin, A. (2004). Introduction: Constructivism and social constructionism in the career field. J ournal of Vocational Behavior, 64(3), 373-388. 
Table 1 Summary of the forms of spousal (non-)support

\begin{tabular}{|c|c|c|c|}
\hline Forms of spousal support & T arget of support & $\begin{array}{ll}\begin{array}{l}\text { Spouse's } \\
\text { behaviours }\end{array} & \text { support }\end{array}$ & $\begin{array}{l}\text { Illustrations from the research } \\
\text { material }\end{array}$ \\
\hline Psychosocial support & $\begin{array}{l}\text { Women managers as } \\
\text { individuals: support } \\
\text { contributes to career } \\
\text { indirectly }\end{array}$ & $\begin{array}{l}\text { Support behaviour is } \\
\text { narrated as being both } \\
\text { explicit and tacit, meaning } \\
\text { that the spouse cheers up, } \\
\text { discusses with, and listens } \\
\text { to the woman and } \\
\text { provides a steady and } \\
\text { reliable background for } \\
\text { her career. }\end{array}$ & $\begin{array}{l}\text { (No.23): "He can give me a terrific } \\
\text { lot of support in this sort of } \\
\text { business management. And my } \\
\text { husband is - um - a bank manager. } \\
\text { A nd well he can sort of talk awfully } \\
\text { well about this kind of broad policy } \\
\text { matters." } \\
\text { (No.4.): "It strikes me that as I said, } \\
\text { it's been a great help to me in a way } \\
\text { that I've got a husband. There in the } \\
\text { background as someone supporting } \\
\text { me while I was studying and now in } \\
\text { a way with work. A bsolutely } \\
\text { essential on the personal level." }\end{array}$ \\
\hline H ands-on support & $\begin{array}{l}\text { Women managers' } \\
\text { family and household: } \\
\text { support contributes to } \\
\text { career indirectly }\end{array}$ & $\begin{array}{l}\text { Support behaviour is } \\
\text { narrated as practical and } \\
\text { manual: the spouse takes } \\
\text { care of the children and } \\
\text { household. }\end{array}$ & $\begin{array}{l}\text { (No.1): "But also then the fact that } \\
\text { he's at home, looking after the } \\
\text { children, doing the cleaning, } \\
\text { preparing food, all the jobs, taking } \\
\text { the kids here and there..." } \\
\text { (No.6): "He takes a lot of } \\
\text { responsibility for the family and is } \\
\text { happy for example with the kids. } \\
\text { He knows how to do everything at } \\
\text { home." }\end{array}$ \\
\hline A ssistance to career & $\begin{array}{l}\text { Women managers' } \\
\text { career: } \\
\text { contributes to career } \\
\text { directly }\end{array}$ & $\begin{array}{l}\text { Support behaviour is } \\
\text { constructed as the spouse } \\
\text { contributing to the } \\
\text { woman's work-related } \\
\text { activities, providing } \\
\text { instrumental support for } \\
\text { her work and in his career } \\
\text { making choices which are } \\
\text { advantageous for the } \\
\text { woman's career. }\end{array}$ & $\begin{array}{l}\text { (No.21): "But the fact that my } \\
\text { husband has worked shorter days } \\
\text { has been tremendously helpful. } \\
\text { That has definitely helped." } \\
\text { (No.15): "Y es, I feel that that time } \\
\text { was important just because as I said } \\
\text { we could have made quite the } \\
\text { opposite decision, when his career } \\
\text { might have been different and it } \\
\text { would have been quite possible that } \\
\text { we wouldn't have got to where we } \\
\text { are now." }\end{array}$ \\
\hline Non-support & $\begin{array}{l}\text { Lack of support for } \\
\text { women managers' } \\
\text { career and family }\end{array}$ & $\begin{array}{l}\text { Non-support behaviour is } \\
\text { constructed as the spouse } \\
\text { being unwilling to } \\
\text { provide support for the } \\
\text { woman's career } \\
\text { advancement or help with } \\
\text { the family. Instead he } \\
\text { belittles the woman's } \\
\text { successful career and } \\
\text { achievements, and would } \\
\text { prefer that the woman } \\
\text { stayed at home and took } \\
\text { care of the children and } \\
\text { the housework. }\end{array}$ & $\begin{array}{l}\text { (No.7): "I'm sure we got a divorce } \\
\text { because my husband didn't really } \\
\text { approve of my studying or really } \\
\text { advancing in my career." } \\
\text { (No.10): "It was that dismissive } \\
\text { way of thinking the whole time. } \\
\text { Like at the beginning (of starting } \\
\text { her own business) saying it'Il be } \\
\text { impossible to make a living from } \\
\text { that, that was like the main thing he } \\
\text { said." }\end{array}$ \\
\hline
\end{tabular}


Table 2 Summary of the narratives of evolving spousal support in the course of women managers' careers

\begin{tabular}{|c|c|c|c|}
\hline Name of group of narratives & $\begin{array}{l}\text { Spousal support and } \\
\text { gender relations }\end{array}$ & Content of the narrative & Story line \\
\hline $\begin{array}{l}\text { Harmoniously flourishing } \\
\text { spousal support }\end{array}$ & $\begin{array}{l}\text { Spousal support is } \\
\text { experienced as flourishing } \\
\text { and the gender relation } \\
\text { between the spouses is } \\
\text { constructed as cooperative, } \\
\text { following the equal gender } \\
\text { order pattern. }\end{array}$ & $\begin{array}{l}\text { Spousal support is narrated } \\
\text { as developing in line with } \\
\text { the woman's career from } \\
\text { practical to hands-on to } \\
\text { psychosocial support. }\end{array}$ & 'Happily-ever-after' \\
\hline Irrelevant spousal support & $\begin{array}{l}\text { Spousal support is } \\
\text { experienced as irrelevant } \\
\text { and the woman is } \\
\text { constructed as self- } \\
\text { managing both career and } \\
\text { family spheres in relation } \\
\text { to the spouse; the } \\
\text { traditional gender order in } \\
\text { gender relations between } \\
\text { the spouses is left } \\
\text { untouched. }\end{array}$ & $\begin{array}{l}\text { Spousal support is narrated } \\
\text { as irrelevant to her career. } \\
\text { No crucial support is } \\
\text { constructed as received or } \\
\text { even sought from the } \\
\text { spouse. }\end{array}$ & Stable \\
\hline $\begin{array}{l}\text { Quitting deficient spousal } \\
\text { support }\end{array}$ & $\begin{array}{l}\text { Spousal support is } \\
\text { experienced as deficient } \\
\text { and the gender relation } \\
\text { between the spouses is } \\
\text { constructed as unequal and } \\
\text { with a yearning for the } \\
\text { traditional gender order; } \\
\text { however, finally that } \\
\text { particular spousal } \\
\text { relationship is left behind, } \\
\text { resulting in the traditional } \\
\text { gender order pattern being } \\
\text { challenged and questioned } \\
\text { but finally left the same } \\
\text { because the relationship is } \\
\text { abandoned. }\end{array}$ & $\begin{array}{l}\text { Only minimal support } \\
\text { from the husband is } \\
\text { narrated as being available. } \\
\text { The spouse is constructed } \\
\text { as a partner who may } \\
\text { provide some practical } \\
\text { hands-on support and even } \\
\text { in some cases career } \\
\text { assistance - usually when } \\
\text { urgently needed and asked } \\
\text { for - but support is hardly } \\
\text { ever psychosocial in } \\
\text { nature. }\end{array}$ & Romance \\
\hline Inconsistent spousal support & $\begin{array}{l}\text { Spousal support is } \\
\text { experienced as inconsistent } \\
\text { and the gender relation } \\
\text { between the spouses is } \\
\text { constructed as if looking }\end{array}$ & $\begin{array}{l}\text { The spousal support is } \\
\text { narrated as inconsistent: } \\
\text { one day supportive, } \\
\text { another day non- } \\
\text { supportive. The woman }\end{array}$ & Tragedy \\
\hline
\end{tabular}




\begin{tabular}{|l|l|l|l|}
\hline & $\begin{array}{l}\text { for a way between equal } \\
\text { and traditional gender } \\
\text { order patterns. }\end{array}$ & $\begin{array}{l}\text { manager is constructed as } \\
\text { receiving hands-on support } \\
\text { and some career assistance } \\
\text { from her spouse. }\end{array}$ & \\
\hline
\end{tabular}

